A cross-national mixed-method study of reality pedagogy

George Sirrakos, Jr. and Barry J. Fraser

Contact author:

Barry J. Fraser ( $\square)$

George Sirrakos, Jr.

Kutztown University of Pennsylvania

Beekey Education Center

PO Box 730

Kutztown PA 19530

Barry J. Fraser

Curtin University

Science and Mathematics Education Centre

GPO Box U1987

Perth Western Australia 6845

Telephone: $\quad$ +61892667896

Fax: $\quad$ +61892662503

Email: $\quad$ B.Fraser@curtin.edu.au 


\section{A cross-national mixed-method study of reality pedagogy}

Abstract This mixed-methods cross-national study investigated the effectiveness of reality pedagogy (an approach in which teachers become part of students' activities, practices and rituals) in terms of changes in student perceptions of their learning environment and attitudes towards science. A questionnaire was administered to 142 students in grades 8-10 in the Bronx, New York City and Dresden, Germany. The questionnaire combines learning environment scales from the Constructivist Learning Environment Survey (CLES) and the What Is Happening In this Class? (WIHIC) questionnaire with attitude scales from the Test of Science-Related Attitudes (TOSRA). Student interviews were used to support questionnaire findings. Quantitative data analyses revealed that reality pedagogy had a greater impact on students in the Bronx than in Dresden, with qualitative data clarifying differences in how reality pedagogy was enacted in each geographic area. Overall, our findings add to the body of evidence concerning the effectiveness of reality pedagogy as an approach to teaching and learning science across a variety of contexts.

Keywords Cross-National, Learning Environments, Mixed-Methods, Reality Pedagogy, Science Education, Student Attitudes

\section{Introduction}

The science achievement gap between the United States and the most economicallydeveloped countries remains at the forefront of the United States' education concerns (Miller and Warren 2011). Every three years beginning in 2000, the Organization for Economic Cooperation and Development (OECD) administered the Program for International Student 
Assessment (PISA) to a sample of 15-year-old students from various countries, in order to explore students' abilities in applying their knowledge and skills in reading, mathematics and science to solve real-world problems (OECD 2013). Results from the 2006 PISA revealed that the United States scored significantly lower than the OECD average on the science literacy scale (Baldi, Jin, Skemer, Green and Herget 2007). Despite some improvement in the 2012 PISA, the United States' scores for the science literacy scale still ranked lower than most of its largest economic partners, including Germany (OECD 2013). Data gathered through the 2012 PISA also revealed disparities in science education within the United States. For example, more than one-third of students sampled who attended high-poverty schools scored at the lowest levels of proficiency on the science literacy scale compared to only $3 \%$ of students attending low-poverty schools. Further, approximately $38 \%$ of Black students and $27 \%$ of Hispanic students sampled also scored at the lowest levels of proficiency compared with 9\% of White students (NCES 2012). This level of proficiency indicates a student's inability to participate actively in science-related life situations and in the labour market (OECD 2013).

The PISA data are alarming for several reasons. First, the United States is one of the wealthiest nations in the world and spends more on education per student than other economically-developed countries (OECD, 2011), yet US students are not performing as well on international science assessments. Next, while factors such as less resources, a greater number of inexperienced teachers, and lower funding are part of high-poverty schools often attended by Black and Hispanic students (Barton and Yang 2000), these cannot be solely responsible for students' poor performance in science classrooms in the United States. Thus there is a need to investigate current instructional practices and trends in the science classroom that often label Black and Hispanic students as disengaged and poor-performing. 
Through this study, we proposed to fill a gap in the education literature by interrogating of the following question: How effective is reality pedagogy in the Bronx (New York) and Dresden (Germany) in terms of students' (a) classroom learning environment perceptions and (b) attitudes to science? In the literature review below, the constructs central to this research question are considered in turn: reality pedagogy; assessment of learning environment; and assessment of attitudes to science.

\section{Literature review}

Reality pedagogy

Reality pedagogy provides opportunities for teachers to immerse themselves in the practices, rituals and artifacts are what drive students to feel, think and act in particular ways (Cobern 1996). Thus, through the opportunities provided by reality pedagogy for the teacher to be a part of student activities, practices and rituals, a more accurate reflection of student culture in the classroom can be delivered during instruction (Emdin 2010, 2011).

Reality pedagogy involves the strategic enactment of certain practices that feed into the nature of instruction in the classroom and which have been developed from years of research conducted in classrooms in two large cities in the Northeastern United States, namely, New York City and Philadelphia (Beers and LaVan 2005; Emdin 2007, 2010; Seiler and Elmesky 2007; Tobin, Elmesky and Seiler 2005; Tobin and Roth 2005). In these studies, certain practices were enacted as a means for improving urban science instruction, and then evaluated for their effectiveness. A study of these successful practices indicated that there were three paths to successful urban science teaching (Emdin 2007). However, further research uncovered that the earlier three dimensions, without a focus on content and context, 
would not reach their potential as facilitators of successful classroom practice. These foci for urban science teaching are cogenerative dialogues, co-teaching, cosmopolitanism, context studies, and content understanding - which have been referred to as the $5 \mathrm{Cs}$ of reality pedagogy (Emdin 2010).

The cogenerative dialogue (cogen), the first $\mathrm{C}$ of reality pedagogy, was developed by Roth, Lawless and Tobin (2000) as a practice of deconstructing lessons for the purpose of improving teaching and learning by providing participants with opportunities to reflect on specific aspects of lessons, critique teaching strategies and discuss barriers to engagement. Cogens are weekly, out-of-class conversations populated by four to six students, each holding a slightly different outlook on the classroom and their teacher. Participation is rotational in that individual students participate in no more than three cogens per semester before being asked to invite a classmate to take his/her place (Beers and LaVan 2005; Emdin 2011). Participants are positioned in a circle with established norms about equal turns at talk and mutual respect. At the end of each cogen, the participants must co-generate a plan of action that the entire group of participants can undertake to improve teaching and learning in the science classroom (Roth, Lawless and Tobin 2000). According to Tobin (2006, p. 138), cogens can "lead to resolutions for enacting teaching in particular ways, rationales for events and practices, and commitments to practices that emerge and conform to particular values and ethics."

Co-teaching, the second of the $5 \mathrm{Cs}$, is a process that allows the student to take on the role of teacher. Traditional versions of co-teaching generally involve interprofessional collaboration between teachers at different stages of their careers (Tobin and Roth 2005) or from different disciplines, such as a specific content area and special education, with the goal of improving teacher practice (Reinhiller 1996). Co-teaching, as used in this study, extends beyond the goals of traditional co-teaching by positioning students from various backgrounds 
as the professionals in the distinct domains that affect the classroom (Emdin 2010). Coteaching in reality pedagogy can be achieved through two processes called the Buddy System and the Student as Teacher (Emdin 2011). Both of these processes involve students connecting with their peers and enacting the responsibilities of the teacher. With the Buddy System, higher-performing students partner with lower-performing students and a space is created in the class where these groups can meet and support each other with the learning of scientific content. The Student as Teacher arrangement allows students to co-plan with the teacher, make decisions about what methods of teaching are likely to be effective, review the topic that will be taught in class, collectively decide on assignments, and then teach the lesson to their peers. As a result of co-teaching, the teacher is able to improve future instruction by adopting the students' pedagogical techniques that were deemed effective (Tobin and Roth 2005).

Cosmopolitanism, the third dimension of reality pedagogy, is a philosophical understanding that focuses on the notion that everyone is a citizen of the world. According to Appiah (2006), the boundaries that exist between cultures are morally irrelevant and, thus, each person has a responsibility for ensuring that all people are treated equally. In the context of urban classrooms, cosmopolitanism focuses on developing deep connections with students across racial, ethnic, linguistic and gender categories so that they can get the most from their classroom experience (Emdin 2011). By beginning with an acknowledgement of the differences that exist without placing more value on any one particular identity, the teacher makes it clear that there is a collective responsibility to ensure that everyone learns about how to support each other in learning science (Emdin 2007). This cosmopolitan classroom provides students with the opportunity to understand their unique role that they will play in the classroom. 
The fourth $\mathrm{C}$ of reality pedagogy is content understanding. In reality pedagogy, content understanding also refers to finding multiple ways to deliver the content. Teachers not only need to know the science content, but also have an understanding of how to engage in conversations with students about it (Magnusson, Krajcik and Borko 1999). Emdin (2011) asserts that the goal is not to change science or re-establish which topics are parts of the curriculum, but rather to shift understanding about how specific science topics in the classroom can best be delivered.

The final dimension of reality pedagogy is context, which refers to the spaces outside the classroom of which students are a part, the use of both physical and symbolic artifacts from these out-of-school spaces, and interrelated phenomena such as cultural traditions and ways of knowing and being (Seiler 2001). Context, in relation to reality pedagogy, requires a level of comfort with students' cultural artifacts that makes it easy for the teacher to pull the context (through artifacts) into the classroom. Artifacts can be either tangible phenomena (such as rocks from a local park or an object that students use in their everyday lifeworlds), symbolic (such as stories about the neighbourhood) or information about the history of students' neighborhoods (Emdin 2007). The practice of connecting students' artifacts with learning allows the subject matter to be more relevant to students and thus increases the teacher's effectiveness.

Assessing students' perceptions of the learning environment

Over the last few decades, learning environment research has been advanced through the use of a number of questionnaires which enable researchers to investigate the classroom learning environment through the eyes of the participants (beta press) rather than through the eyes of an external observer (alpha press) (Murray 1938). Instruments such as the Learning Environment Inventory (LEI), My Class Inventory (MCI), Science Laboratory Environment 
Inventory (SLEI), Questionnaire on Teacher Interaction (QTI), Constructivist Learning Environment Survey (CLES) and the What Is Happening In this Class? (WIHIC) questionnaire have been used to assess specific psychosocial dimensions of classroom learning environments (Fraser 2012). For this study, a combination of scales from the CLES and the WIHIC were used to assess student perceptions of their learning environment.

The CLES was developed to assist "researchers and teachers to assess the degree to which a particular classroom's environment is consistent with a constructivist epistemology, and to help teachers to reflect on their epistemological assumptions and reshape their teaching practice" (Fraser 2007, p. 107). While this study did not aim to measure constructivism directly, there are certain aspects of constructivism that underlie the practice of reality pedagogy, therefore making the CLES relevant and appropriate for our study. The CLES has five scales with a total of 36 items: Personal Relevance, Uncertainty, Critical Voice, Shared Control and Student Negotiation (Taylor, Fraser and Fisher 1997). The CLES has five frequency response alternatives, namely, Almost Never, Seldom, Sometimes, Often, and Very Often. The CLES presents these items in blocks with the first set of items referring to Personal Relevance, the second set referring to Uncertainty of Science, and so on. The scales are useful for determining whether specific dimensions of a constructivist classroom exist and provide a basis for the investigation of the usefulness of innovative teaching methods (Nix, Fraser and Ledbetter 2005).

Researchers have used the CLES to measure students' perceptions of constructivist learning environments of science classes in the United States, Australia, Taiwan and Korea (Aldridge, Fraser, Taylor and Chen 2000; Nix et al. 2005; Oh and Yager 2004), in South Africa and the United States in mathematics classes (Aldridge, Fraser and Sebela 2004; Ogbuehi and Fraser 2007), and in classes with an emphasis on the use of technology to deliver the curriculum (Luan, Bakar, Mee and Ayub 2010). The CLES has also been used to 
evaluate the effectiveness of innovative curricula (Spinner and Fraser 2005) and teacher development programs (Johnson and McClure 2004; Koh and Fraser 2014). These studies have supported this questionnaire's strong factor structure and reliability in a variety of global classroom settings and in a variety of languages. In addition to these studies, other research has made use of the CLES but the primary goals didn't include validation of the CLES with a large sample (Beck, Czerniak and Lumpe 2000; Ozkal, Tekkaya, Cakiroglu and Sungur 2009).

The WIHIC questionnaire has seven scales, each with eight items, that assess Student Cohesiveness, Teacher Support, Involvement, Investigation, Task Orientation, Cooperation and Equity. The items in the questionnaire are organised in blocks by scale. All items have the frequency responses of Almost Never, Seldom, Sometimes, Often, and Almost Always (Aldridge, Fraser and Huang 1999).

Researchers have used the WIHIC to measure students' perceptions of classes in geography (Chionh and Fraser 2009), mathematics (Afari, Aldridge, Fraser and Khine 2013; Fraser and Raaflaub 2013; Taylor and Fraser 2013), science (Aldridge, Laugksch, Seopa and Fraser 2006; Giallousi, Gialamas, Spyrellis and Pavlatou 2010; Helding and Fraser 2013; Robinson and Fraser 2013), and classes with an emphasis on the use of technology to deliver the curriculum (Aldridge, Dorman and Fraser 2004; Aldridge and Fraser 2008; Oser and Fraser 2015). The WIHIC has also been used to investigate relationships between the learning environment and educational variables including academic efficacy and use of information technology (Zandvliet and Fraser 2004), gender differences in perceptions of the learning environment from within the same classroom situation (Kim, Fisher and Fraser 2000), and culture and language differences between groups (Koul and Fisher 2005). The WIHIC has also been used in cross-national studies comparing learning environments in different countries including Australia, the United Kingdom, Canada, Cyprus, Taiwan and 
Indonesia (Aldridge, Fraser and Huang 1999; Fraser, Aldridge and Adolphe 2010; Giallousi, Gialamas, Spyrellis and Pavlatou 2010). Finally, the WIHIC has also been used extensively to study associations between classroom learning environment factors and subject-specific attitudes (Aldridge, Laugksch, Seopa and Fraser 2006; Fraser 2012). The reliability and validity of the WIHIC have been widely reported in studies that have used the instrument in different subject areas, at different age levels and in numerous countries (Fraser 2014).

Student attitudes and the Test of Science Related Attitudes (TOSRA)

Our study of the effectiveness of reality pedagogy also involved attitude criteria. Attitudes can involve the intensity of positive or negative affect for or against a psychological object to which an opinion has been expressed (Thurstone 1928). For this study, the Test of Science Related Attitudes (TOSRA) was selected as the instrument for collecting data about students' attitudes towards science. TOSRA contains 70 items divided into seven distinct scales: Social Implications of Science, Normality of Scientists, Attitude to Scientific Inquiry, Adoption of Scientific Attitudes, Enjoyment of Science Lessons, Leisure Interest in Science, and Career Interest in Science (Fraser 1978, 1981). Each item follows a Likert scaling format and is scored 1, 2, 3, 4 and 5, respectively, for the responses of Strongly Disagree, Disagree, Neutral, Agree and Strongly Agree. Some items are negatively worded and therefore are scored in reverse.

Fraser, Aldridge and Adolphe (2010) used the TOSRA and the WIHIC to investigate the relationship between the learning environment and students' attitudes in Australia and Indonesia. Analyses of data from both countries attested to the TOSRA having satisfactory factorial validity and internal consistency reliability. In addition, researchers have used modified versions of the TOSRA to measure students' attitudes towards mathematics 
(Ogbuehi and Fraser 2007; Spinner and Fraser 2005), geography (Walker 2006), chemistry (Wong and Fraser 1996), English (Liu and Fraser 2013), Spanish (Adamski, Fraser and Peiro 2013) and classes that are technology-rich (Aldridge and Fraser 2008). Further, the TOSRA has also been used to evaluate innovations (Lott 2003), to compare the attitudes of different groups of students (Joyce and Farenga 2000) and to explore associations between the learning environment and students' attitudes (Fraser and Fisher 1982; Wong, Young and Fraser 1997)

\section{Research methods}

Participants

Data were obtained from a total sample of 142 general-education students in grades 8-10 from two distinct groups of students from the Bronx, New York and Dresden, Germany. Of these 142 students, 82 were from five science classes at the International School of Dresden (ISD), which consists of a primary and secondary school and has a grade 6-12 enrolment of approximately 300 students coming from a range of countries including Germany, United States, Australia, Japan and Singapore, as well as from diverse socioeconomic settings. Because the diverse nature of the students involved is not indicative of the diversity of the city of Dresden, this sample is not consistent with many other high schools in the area, but it is comparable to other international schools located throughout Germany. The other 60 students were from two science classes at Bronx High School (BHS), which is a small public school located in the Bronx with approximately 350 students spanning grades 9-12. The student population of BHS is predominantly Latino and African-American and students (close to 90\%) qualify for free or reduced-cost lunch, indicating that they come from socioeconomic backgrounds indicative of traditionally marginalised students. The sample is 
consistent with many other high schools in the area, as well as with the overall demographics of the Bronx. In both of these schools, class sizes ranged from 20 to 30 students, with boys and girls being approximately equally represented, thus reducing any possible gender biases in the data.

Quantitative and qualitative data collection

As recommended by Cresswell (2008) and Tobin and Fraser (1998), this exploratory study combined quantitative and qualitative methods in evaluating reality pedagogy in terms of student perceptions of their learning environment and student attitudes toward science. Questionnaires provided an inexpensive and efficient way to gather data about students' perceptions of the learning environment and their attitudes toward science from a large ‘coarse grain' sample of students (Aldridge and Fraser 2000). Semi-structured interviews of urban-American and German-international students provided additional validity for a smaller ‘fine grain' sample of students (Greene and Caracelli 1997).

To form a questionnaire for use in this study, we combined scales selected from two widely-used learning environment instruments, the What is Happening In this Class? (WIHIC) questionnaire and the Constructivist Learning Environment Survey (CLES), together with two student attitude scales from the Test of Science-Related Attitudes (TOSRA). While the three questionnaires have been in existence for some time, combining selected scales created a 'new' questionnaire whose validity and reliability needed to be checked. We named our instrument the Questionnaire Assessing the Learning Environment and Student Attitudes (QuALESA) and we administered it to the participants in August 2010 (pretest) and June 2011 (posttest). Because of the small sample size for each population, we conducted validity and reliability analyses by combining the participants into a single sample. 
Table 1 provides a scale description and sample item for each scale used from the CLES, WIHIC and TOSRA. In order to better correspond to the layout of the final instrument used in this study, certain modifications were made. First, the five-point Likert agreement scale associated with the TOSRA was changed to the same five-point frequency scale, with response alternatives ranging from Almost Always to Almost Never as for the CLES and WIHIC. Some of the TOSRA items were reworded slightly to allow them to fit better with the new response alternatives. Finally, because many of the participants in the study were not native English speakers, negatively-worded items were modified to be positively worded. The diverse ethnicities of the student populations at the two schools prompted the translation of the questionnaire into Spanish and German as recommended by Brislin (1970). This process allowed the production of two versions of the questionnaire: an English-German version and an English-Spanish version. To ensure that students truly understood what they were reading, the corresponding German or Spanish item followed each English item.

Table 1 about here

Semi-structured key informant interviews were used to assess and further investigate changes in student perceptions of the learning environment (Anderson 1998; Lindlof and Taylor 2011; Morgan 1997). Using a semi-structured format provided the flexibility of basing questions on themes that we wished to explore rather than using a set of rigid questions. In conducting effective interviews, guidance was obtained from sources such as Patton (2002), Erickson (2012), Denzin and Lincoln (2008) and Kvale (1996). In an attempt to maximises the rigour, reliability and dependability of the interviews, insights were gleaned from Cresswell and Plano Clark (2007) and Lincoln and Guba (1985). 
Semi-structured interviews lasting approximately 15 minutes were conducted with six students (three from ISD and three from BHS) from five different science classrooms (three from ISD and two from BHS) throughout the course of the study. Each student was interviewed between four and six times throughout the academic year. The purpose of the semi-structured interviews was to provide the researchers with insight and student perspectives regarding specific events that occurred in the classroom. Each interview used the following questions as starting points:

Have you noticed anything different about your learning environment?

Do you have any suggestions for the improvement of any future science lessons?

Has anything occurred in the classroom which prevented you from learning?

Participants were not bound by these specific questions and new questions particular to the context of the interview and the individual being interviewed often arose as a result of a participant's responses (Lindlof and Taylor 2011).

To ensure fluidity of the interview, interviewers did not take notes. Rather, interviews were audiotaped and later transcribed to ensure accuracy. At the conclusion of each interview, the interviewers provided the participant with an oral summary of the major points discussed to ensure that the interviewer had accurately captured the contents of the interview.

\section{Data analyses and findings}

Once the QuALESA had been shown to be valid and reliable through factor and reliability analyses, student responses were analysed further to investigate differences between science students from the Bronx and Dresden in terms of their classroom learning environment perceptions and attitudes to science. During the time between pretest and posttest 
administrations of the QuALESA, qualitative data were collected from semi-structured interviews to provide students with opportunities to elaborate their thoughts regarding the learning environment and their attitudes towards science while they were experiencing reality pedagogy.

Validity of QuALESA

For this study, factor analysis was carried out using principal axis factoring with varimax rotation and Kaiser normalization to check the structure of the 46-item, seven-scale questionnaire. A separate analysis was conducted for the pretest data and the posttest data for the QuALESA. Each of these analyses was carried out using combined data collected from both the Dresden and Bronx samples. Although validity analyses for these two samples ideally would have been conducted separately, the small sample size for each population necessitated combining the participants into a single sample. Neverless, preliminary separate analyses of data for each sample displayed patterns similar to the combined sample, adding confidence to the results of our validity analyses.

The Appendix shows the factor loadings for the QuALESA for the pretest and posttest for the entire sample. Additionally, the percentage of variance and eigenvalue for each scale can be found at the bottom of the Appendix. In order for any item to be retained, it had to have a loading of at least 0.35 on its own scale and less than 0.35 on all other scales. All 46 items in the Appendix satisfied these criteria and therefore were retained. The percentage of variance for the pretest ranged between $4.58 \%$ to $22.73 \%$ and the eigenvalue ranged between 2.06 and 10.23 for different scales. The total proportion of variance accounted for by these 46 items in seven scales was $59.9 \%$. The percentage of variance for the posttest ranged 
between $3.95 \%$ to $21.77 \%$ and the eigenvalue ranged between 1.81 and 10.01 . The total proportion of variance accounted for by these 46 posttest items in seven scales was $59.8 \%$.

Cronbach's alpha coefficient was used as an index of internal consistency reliability to check that each of the items making up a scale in the QuALESA reflected a common construct. The bottom row of the Appendix shows that the alpha reliability coefficient was high for all scales for both the pretest and posttest. Alpha coefficients for the learning environment scales for the pretest ranged from 0.72 for Involvement to 0.86 for Personal Relevance and for the posttest from 0.76 for Involvement to 0.87 for Critical Voice. Alpha coefficients for the attitude scales for the pretest were 0.88 for Attitude to Scientific Inquiry and 0.94 for Enjoyment of Science Lessons and for the posttest were 0.87 for Attitude to Scientific Inquiry and 0.92 for Enjoyment of Science Lessons. These results attest to the QuALESA's strong internal consistency reliability.

Differences in learning environment perceptions and attitudes to science between the Bronx and Dresden

To investigate the statistical significance of differences between the Bronx and Dresden in terms of students' perceptions of the learning environment and attitudes toward science, scores for each scale of the QuALESA were statistically analysed using MANOVA. Analyses were conducted separately for pretest and posttest data. The multivariate test using Wilks' lambda criterion, which provided protection against a high Type I error rate, revealed a statistically significant change in the set of seven learning environment and attitude scales as a whole. Therefore the individual univariate ANOVA was interpreted separately for each dependent variable. Effect sizes were also calculated in conjunction with traditional significance testing in order to provide further information about the magnitudes, and therefore the educational importance, of differences (Cohen 1992). The effect size $(d)$ was 
calculated by dividing the difference between pretest and posttest means by the pooled standard deviation.

Table 2 shows descriptive statistics, including means and standard deviations, as well as ANOVA results and effect sizes for between-country differences. Figure 1 graphically compares the average item mean (scale mean divided by the number of items associated with that scale) for both samples for the QuALESA scales administered before (pretest) and after (posttest) the implementation of reality pedagogy, respectively.

Differences in QuALESA scores between Dresden and the Bronx for the pretest ranged from 0.18 standard deviations for Shared Control to 1.09 standard deviations for Critical Voice. For the scales of Involvement, Cooperation, Personal Relevance, Critical Voice, Attitude to Scientific Inquiry and Enjoyment of Science Lessons, between-country differences at pretesting were statistically significant and were $0.65,0.58,0.86,1.09,0.56$ and 0.94 standard deviations, respectively, which represent medium and large effect sizes (Cohen 1992). In contrast, for the posttest, differences between Dresden and the Bronx were statistically nonsignificant and were associated with effect sizes ranging from only 0.03 standard deviations for Shared Control to 0.29 standard deviations for Personal Relevance, which are small effect sizes according to Cohen (1992).

A graphical comparison of QuALESA average item mean scores for Dresden and the Bronx for the pretest and posttest can be viewed in Figure 1. Whereas there were large and statistically significant differences for all learning environment and attitudes scales except Shared Control between Dresden and the Bronx for the pretest, these differences became much smaller and were nonsignificant for the posttest. That is, by the time of the posttest, all of the sizeable and significant differences between Dresden and the Bronx that had been present for the pretest had disappeared. 
As shown in Table 2, for nearly all the pretest QuALESA scales, students in Dresden had significantly higher scores than students from the Bronx. However, upon closer examination, one can see that the learning environment perceptions and attitudes towards science changed little between the pretest and posttest for the Dresden sample. In contrast, the Bronx sample exhibited sizeable pre-post changes in average item means for all scales. By the time of the posttest, the average item mean scores for the Bronx population had become more closely aligned with the average item mean scores for students in Dresden. One interpretation of this could be that reality pedagogy had a greater impact for the Bronx sample than the Dresden sample.

Semi-structured interview responses to support findings from the QuALESA

Analysis of semi-structured interviews clarified differences between the Bronx and Dresden in terms of students' perceptions of their learning environment and their attitudes towards science. The transcribed interviews were reviewed and a tally was taken to identify some of the most frequently-occurring topics and issues. At the conclusion of each semi-structured interview, the content was organised in the form of vignettes to reflect the identified common themes, individual perspectives, and components of reality pedagogy. Below are some student interview responses which explain and illuminate the changes for certain QuALESA scales.

Differences in Cooperation. Engagement in reality pedagogy prompted teachers to provide students with more opportunities to cooperate. In turn, increased exposure to activities requiring cooperation allowed students to practise and refine their communication skills and show empathy towards their classmates. The interview responses of students from the Bronx 
described a preference for implementation of activities that foster cooperation through the scientific inquiry process, particularly through the acts of questioning, collaboration and selfexploration as paths towards understanding science content. Simone and Jasmine, students from the Bronx, had the following to say:

Personally, I know that, if we had more group work where we had to figure out some sort of challenge, then I would probably engage in the work more.

Instead of the teacher talking most of the time, there could be some sort of activity where we could work together. Last week, the teacher started to do something like this and it was one of the first times I was listening in class. Students were split up into four groups which we chose. Each group was given an article dealing with science and that was related to our everyday life. This was different because usually the teacher would never really focus on why things were relevant for us to learn. He would just say "you need to know this for later on" without explaining specifically for what. With the article we were given, our group had to summarise and present the information to the rest of the class, without drowning everyone with the specific data. Everyone in our group worked and, even though the data wasn't from New York but from California, I could imagine that life there isn't very different. Also, the presentations allowed us to hear from our classmates, rather than just from the teacher. This is a good idea, but I think the really important information should still be taught by the teacher to make sure that all students fully understand it. Giving us the chance to do work and learn in this way, in my opinion, was a good thing.

As a reaction to these interview responses, the teacher began to allow students the opportunity to cooperate and work alongside classmates of their choosing. Cooperation was also fostered through changes in the teacher's practice, such as the inclusion of more group work and more open-ended questions to allow discussion.

In contrast, according to students in Dresden, even prior to this research study, teachers had been modifying their instruction to increase cooperation in the science classroom. Thus, student responses in Dresden might appear more thoughtful, but this was only because some of the more basic approaches to increasing cooperation were already being implemented. 
Students from Dresden described cooperation as a purposeful act, driven by a desire to see others succeed. Lance, a student from Dresden, said:

\begin{abstract}
I noticed that my friend wasn't really paying attention to the class and what was being dicussed. So, I thought it was my job to talk to my friend and figure out what his problem was. I guess this is what the teacher meant by 'true cooperation'. Now I feel responsible for working with my friend to get him to focus and help him if he needs help. Also, I feel that this type of cooperation will help us have a longer lasting influence on the science class. It's more than just about making an interesting activity or cool lesson. As students, we really need to be active and always figure out ways to improve the class. Luckily, our teacher is ok with us taking on that role.
\end{abstract}

Differences in Critical Voice. In addition to increased cooperation, another objective of reality pedagogy is to establish an environment that encourages students to question and critique the teaching and learning activities occurring in the classroom. When students from the Bronx were interviewed, their responses revealed concerns that were almost exclusively about how the teacher teaches. Many of these students felt comfortable in sharing their critiques of the classroom instruction with the interviewer, but expressed their discomfort with sharing their thoughts directly with the teacher. Jasmine, a student from the Bronx, conveyed the following sentiment that explained how many students felt toward criticising the teacher:

Usually, nobody really wants to admit if they don't understand something and no-one is going to tell the teacher anything about him not doing a good job. I mean, the teacher is supposed to be the expert, not us. He should realise if his explanations make sense and should always make sure that he is explaining things in a way that not only make sense to him. I also think the teacher should be asking us more questions to make sure we understand something and to come around more often to check.

However, because reality pedagogy is meant to be an organic process for which students determine what effective instruction is within their specific context, it is important 
that students build the confidence to express their critical voice to the teacher. As students noticed that the teacher was making an honest and concerted effort to improve the learning environment, they began to share their critiques of classroom instruction more frequently and in greater detail. Simone, another student from the Bronx, said:

Thinking back to some of our classes lately, we have been able to talk to the teacher more about what he is doing and he has definitely started to use a lot more of our suggestions when he teaches.

Conversely, when students from Dresden were interviewed, many of their responses revealed a concern with being able be a part of the creation of assessments at every point in the process, from the initial brainstorming to the grading criteria. The primary criticism of the teacher appeared to be his lack of communication with students regarding assessment of student learning and understanding. Additionally, unlike students from the Bronx, the students from Dresden took no issue with expressing their critical voice to the teacher, both during and after the science lesson.

Kim, a student from Dresden, shared her thoughts on how she would have changed an assessment. This was interesting because, typically, after the completion of an assessment, students would not offer any criticism because they believed that their feedback was irrelevant because the assessment had already passed. However, Kim's response, in reference to an assessment that involved students in building a model of DNA and writing an accompanying essay, indicated her belief that the teacher might use her critique of the assessment to improve future assessments:

If I could change it, I would have had the essay as a separate grade, because one part of the assignment had little to do with the other except for the topic. It was okay to review the history, but the structure of DNA and how it communicates information could have been excluded, as we had done this already in class. The word limit of 1000 words was very short if all of these 
things had to be included, and so there was barely space for explaining the use of DNA knowledge and the evaluation of sources. Therefore, either the word limit should be increased or the structure and how DNA communicates information should be excluded from the essay, as one could focus more on the unknown situations relating to DNA.

Differences in shared control

As interview responses were analysed, the sharing of control emerged as the most common response about how students felt that the science class changed over the year. As a consequence of the teacher sharing control with the students, there was an increase in personal relevance during instruction and in assessments. However, the manner in which students decribed changes in shared control differed with geographic area. Kim, a student from Dresden, described shared control as including students in the creation of assessments and classroom learning activities:

The teacher asks about how we might change assignments to make them more interesting. I really enjoy that the teacher involves us in planning the assignments.

By assisting the teacher in such a capacity, Kim pointed out that students were able to ensure that the assessments and learning activities were indicative of students' realities and not the teacher's perception of them. Thus, Kim described two assessments which were a result of the shared control between the teacher and students:

Our cogenerative dialogue group and the teacher had planned a celebrity genetics poster assignment. The assessment made students create a large number of Punnett squares, allowing even the slowest-learning student the opportunity to practice and understand them. It linked to the out-of-school life of students, so that there might have been extra motivation to score high on this assignment. We also helped the teacher plan a lesson on food. We compared foods to see how much of something is in a product in relation to another product. We also compared diet products with normal products and found that to be interesting. The differences between the two were minimal and this is important to know, as some people might grab the diet product thinking that they're doing better for their body. I just feel that this lesson was related very much to our everyday life. 
With regard to reality pedagogy, the sharing of control as described by Kim is parallel to the coteaching component of reality pedagogy. Coteaching allowed Kim and her cogenerative dialogue peers to function as professionals in the science class by taking on the responsibility of creating relevant assessments and activities. In consultation with the teacher, this process of co-teaching ensured that decisions that would positively affect students' learning were being made and that all of the students in the class benefited. Associated with this coteaching practice is the idea of cosmopolitanism. The process of sharing control provided students with the opportunity to better understand the culture of teaching, whereas the teacher was given the opportunity to delve more deeply into the culture of international school youth. Additionally, Kim alluded to the fact that the purpose of the decisions that were being made during the cogenerative dialogue were to enable all students to get the most from their classroom experiences. Hence, in line with reality pedagogy, such effective use of coteaching was possible because of the development and mutual understanding of the culture and personal experiences being brought into the classroom by each student. Grace, another student from Dresden, stated:

\begin{abstract}
My science teacher always says that "there is no such thing as a stupid question" and is always asking us to ask questions about the topic we are learning. And because it's my question and requires me to do some research, I usually remember the information better. I know I'm not the smartest student in the class but I feel comfortable asking a lot of questions, because I know that, otherwise, I'm not going to be simply told an answer. The teacher typically tries to relate what he is teaching to our lives and that makes it more interesting.
\end{abstract}

Grace's response painted a slightly different picture of shared control in the classroom. Traditionally, the asking of questions is a privelege reserved for the teacher. The teacher generates the questions and students, hopefully, respond. In Grace's description of the classroom, the teacher partially gave up this responsibility and shared it with students, thereby empowering them to ask questions during the lesson. 
Students from the Bronx also indicated that they noticed an increase in shared control as the school year progressed. During one interview, Shawn described teacher actions indicative of a teacher who is trying to more closely align scientific knowledge with good pedagogical practices, resulting in his increased satisfaction with the science class. Further, Shawn alluded to the higher level of shared control between the teacher and students as another reason for his increased enjoyment of science lessons:

Science used to be really straightforward. The teacher just sort of talked to us and didn't really give us any chances to do experiments or to investigate something to show that we can learn it. This science class has got better as the year went on in some ways. More activities and experiments and stories that have to do with us. Also, the teacher is giving us options for how to show what we learned and letting us choose how to show our work.

Jasmine, following along the same lines as Shawn, continued to elaborate on shared control in the classroom in the form of coteaching, ultimately leading to increased personal relevance:

The teachers asks us what we are interested in, what we might have questions about, to see if and how it fits in with what he needs to teach us. He has tried to make things more relevant using things we know about like basketball, dance, and music.

In her response, Jasmine made explicit three key cultural artifacts that united many of the Bronx students. Interestingly, while the teacher tried to incorporate these artifacts into science teaching, an aspect of reality pedagogy referred to as context studies, it should be again noted that the teacher's identification of these artifacts resulted from interactions with students, primarily during cogenerative dialogues.

\section{Discussion and summary}


This study is unique in that it married the three distinct research areas of classroom learning environments, student attitudes and reality pedagogy in a study that was both cross-national and mixed-methods. The effectiveness of reality pedagogy, a strategy of teaching that involves gaining insight into students' culture, actions, and attitudes, was evaluated using a classroom environment and student attitude instrument (the QuALESA) adapted from previous studies.

The data analyses revealed large and statistically significant differences between students from Dresden and the Bronx on QuALESA scales at the time of pretesting for the scales of Involvement, Cooperation, Personal Relevance, Critical Voice, Attitude to Scientific Inquiry and Enjoyment of Science Lessons. However, when posttest data were analysed, all of the significant differences that had been previously present no longer existed. For the pretest, effect sizes for between-country differences suggest a 'small' difference for Shared Control (0.18 standard deviations), a ‘medium' difference for Involvement (0.65 standard deviations) and Cooperation (0.58 standard deviations) and a 'large' difference for Personal Relevance (0.86 standard deviations) and Critical Voice (1.09 standard deviations). For the posttest, effect sizes for between-country differences suggest a 'small' difference for all learning environment scales. In a similar fashion, effect sizes for the two attitude scales were larger for the pretest than for the posttest.

The theoretical significance of this research lies in the conjoining of the three distinct research areas of classroom learning environments, student attitudes and reality pedagogy. These fields were investigated simultaneously within a single study in an attempt to set a precedent for further research into the impact of reality pedagogy on students' perceptions of their learning environment and attitudes toward science.

This research is methodologically significant because it is one of few studies that compared classroom learning environments and student attitudes across national borders. It 
explored a wide range of students, urban and international, as opposed to conducting research with a small, confined sample, thus offering "much promise for generating new insights" (Aldridge, Fraser and Huang 1999, p. 48). Further, this research combined quantitative and qualitative methods for obtaining data, which is in contrast to many of the previous studies of reality pedagogy that have solely employed qualitative research methods.

The research is unique because it extended the study of reality pedagogy beyond the traditional urban minority population and moved across national borders to involve a population of students at an international school in Dresden, Germany. Studies of the outcomes of reality pedagogy have traditionally been carried out using a small, confined sample from a large urban area, such as New York City or Philadelphia (Emdin 2007, 2010; Seiler and Elmesky 2007). By exploring reality pedagogy across contexts, we observed that reality pedagogy was successful in transforming teaching practices used to teach science to traditionally marginalised students in the Bronx, but had a relatively small effect on the learning environment perceptions and attitudes of international students in Germany. Thus, the results of this research add to the body of evidence suggesting that urban minority youth can also engage with, enjoy, be interested in and participate in science. We are hopeful that this research will help dispel myths that urban youth are unable to be successful in science and shift the focus to criticising and transforming the current practices used to teach science to traditionally marginalised students.

The practical significance of this research lies in using reality pedagogy and classroom questionnaires to allow traditionally marginalised students greater access to science content and to demonstrate that they can be successful in a subject traditionally not accessible to them. Finally, this study could have practical implications for higher-education teacher preparation programs by encouraging and highlighting the usefulness of reality pedagogy as a relevant tool for science educators. The results of this study support a recent 
push, particularly in universities in the northeast United States, to include practices associated with reality pedagogy in teacher education programs. Therefore, there exists the potential for future science educators to use reality pedagogy as a tool to allow traditionally marginalised students greater access to and success with science content.

While there has already been some research concerning the impact of reality pedagogy, and most of it supports the findings of this study, we recommend that additional similar research is conducted. As additional studies are undertaken, replication of results similar to ours would further support the validity and reliability of the QuALESA, as well as build confidence in reality pedagogy as a pedagogical practice for improving student engagement and participation in science. Another future direction for this type of research would be to involve larger samples of students to provide greater statistical power and give greater confidence in the findings, and to involve a more diverse sample of students from a larger variety of schools and geographic areas to further support the generalisability of findings about the usefulness of reality pedagogy across a variety of contexts. Another research possibility lies in inquiring about students' academic performance when engaging with reality pedagogy. Because our study did not track students' academic performance throughout the academic year, it would be of much interest in future research to investigate whether students not only hold positive perceptions and attitudes, but also whether implementing reality pedagogy also improves their academic performance. Perhaps another future study could compare the effectiveness of reality pedagogy for teachers with teachercentred teaching styles and those with student-centred teaching styles. 


\section{References}

Adamski, A., Fraser, B.J., \& Peiro, M.M. (2013). Parental involvement in schooling, classroom environment and student outcomes. Learning Environment Research, 16, 315-328.

Afari, E. Aldridge, J.M., Fraser, B.J., \& Khine, M.S. (2013). Students' perceptions of the learning environment and attitudes in game-based mathematics classrooms. Learning Environments Research, 16, 151-167.

Aldridge, J.M., Dorman, J.P., \& Fraser, B.J. (2004). Use of multitrait-multimethod modeling to validate actual and preferred forms of the Technology-Rich Outcomes-Focused Learning Inventory (TROFLEI). Australian Journal of Educational and Developmental Psychology, 4, 110-125.

Aldridge, J.M., \& Fraser, B.J. (2000). A cross-cultural study of classroom learning environments in Australia and Taiwan. Learning Environments Research, 3, 101134.

Aldridge, J.M., \& Fraser, B.J. (2008). Outcomes-focused learning environments: Determinants and effects (Advances in Learning Environments Research series). Rotterdam, the Netherlands: Sense Publishers.

Aldridge, J.M., Fraser, B.J., \& Huang, I.T.-C. (1999). Investigating classroom environments in Taiwan and Australia with mutliple research methods. Journal of Educational Research, 93, 48-62.

Aldridge, J.M., Fraser, B.J., \& Sebela, M.P. (2004). Using teacher action research to promote constructivist learning environments in South Africa. South African Journal of Education, 24, 245-253. 
Aldridge, J.M., Fraser, B.J., Taylor, P.C., \& Chen, C.C. (2000). Constructivist learning environments in a cross-national study in Taiwan and Australia. International Journal of Science Education, 22, 37-55.

Aldridge, J.M., Laugksch, R.C., Seopa, M.A., \& Fraser, B.J. (2006). Development and validation of an instrument to monitor the implementation of outcomes-based learning environments in science classrooms in South Africa. International Journal of Science Education, 28, 45-70.

Anderson, G. (1998). Fundamentals of educational research ( $2^{\text {nd }}$ ed.). Bristol, PA: Falmer Press.

Appiah, K.A. (2006). Cosmopolitanism: Ethics in a world of strangers. New York: Teachers College Press.

Baldi, S., Jin, Y., Skemer, M., Green, P.J., \& Herget, D. (2007). Highlights from PISA 2006: Performance of U.S. 15-year-old students in science and mathematics literacy in an international context (NCES 2008-016). Washington, DC: National Center for Education Statistics, Institute of Education Sciences, U.S. Department of Education.

Barton, A.C., \& Yang, K. (2000). The culture of power and science education: Learning from Miguel. Journal of Research in Science Teaching, 37, 871-889.

Beck, J., Czerniak, C.M., \& Lumpe, A.T. (2000). An exploratory study of teachers' beliefs regarding the implementation of constructivism in their classroom. Journal of Science Teacher Education, 11, 323-343.

Beers, J., \& LaVan, S.K. (2005). The role of cogenerative dialogue in learning to teach and transforming learning environments. In K. Tobin, R. Elmesky, \& G. Seiler (Eds.), Improving urban science education: New roles for teachers, students, \& researchers (pp. 147-163). Lanham, MD: Littlefield Publishing Group. 
Brislin, R. (1970). Back translation for cross-cultural research. Journal of Cross-Cultural Psychology, 1, 185-216.

Chionh, Y.H., \& Fraser, B.J. (2009). Classroom environment, achievement, attitudes and self-esteem in geography and mathematics in Singapore. International Research in Geographical and Environmental Education, 18, 29-44.

Cobern, W.W. (1996). Worldview theory and conceptual change in science education. Science Education, 80, 579-610.

Cohen, J. (1992). Statistical power analysis. Current Directions in Psychological Science, 1, 98-101.

Cresswell, J.W. (2008) Educational research: Planning, conducting, and evaluating quantitative and qualitative research ( $3^{\text {rd }}$ ed.). Upper Saddle River, NJ: Pearson.

Creswell, J., \& Plano Clark, V. (2007). Designing and conducting mixed method research. Thousand Oaks, CA: Sage Publications.

Denzin, N, \& Lincoln, Y. (2008). Collecting and interpreting qualitative materials (3rd ed.). Thousand Oaks, CA: Sage Publications Inc.

Emdin, C. (2007). Exploring the contexts of urban science classrooms: Part 1 - Investigating corporate and communal practice. Journal for Cultural Studies of Science Education, 2, 319-341.

Emdin, C. (2010). Urban science education for the hip-hop generation. Rotterdam: Sense Publishers

Emdin, C. (2011). Moving beyond the boat without a paddle: Reality pedagogy, black youth, and urban science education. The Journal of Negro Education, 80, 284-295.

Fraser, B.J. (1978). Development of a test of science-related attitudes. Science Education, $62,509-515$. 
Fraser, B.J. (1981). Test of Science-Related Attitudes. Melbourne, Australia: The Australian Council for Education Research.

Fraser, B.J. (2007). Classroom learning environments. In S.K. Abell \& N.G. Lederman (Eds.), Handbook of research on science education (pp. 103-124). London: Lawrence Erlbaum Associates.

Fraser, B.J. (2012). Classroom learning environments: Retrospect, context and prospect. In B.J. Fraser, K.G. Tobin, \& C.J. McRobbie (Eds.), Second international handbook of science education (pp. 1191-1239). Dordrecht, the Netherlands: Springer.

Fraser, B. J. (2014). Classroom learning environments: Historical and contemporary perspectives. In N.G. Lederman and S.K. Abell (Eds.), Handbook of research on science education (pp. 104-119. New York: Routledge.

Fraser, B.J., Aldridge, J.M., \& Adolphe, F.S.G. (2010). A cross-national study of secondary science classroom environments in Australia and Indonesia. Research in Science Education, 40, 551-571.

Fraser, B.J., \& Fisher, D.L. (1982). Predicting students' outcomes from their perceptions of classroom psychosocial environment. American Educational Research Journal, 19, 498-518.

Fraser, B. J., \& Raaflaub C. (2013). Subject and sex differences in the learning environment Perceptions and attitudes of Canadian mathematics and science students using laptop computers. Curriculum and Teaching, 28 (1), 57-78.

Giallousi, M., Gialamas, V., Spyrellis, N., \& Pavlatou, E. (2010). Development, validation, and use of a Greek-language questionnaire for assessing learning environments in grade 10 chemistry classes. International Journal of Science and Mathematics Education, 8, 761-782. 
Greene, J.C., \& Caracelli, V.J. (Eds.). (1997). Advances in mixed-method evaluation: The challenges and benefits of integrating diverse paradigms (New Directions for Evaluation, No.74). San Francisco: Jossey-Bass.

Helding, K.A., \& Fraser, B.J. (2013). Effectiveness of National Board Certified (NBC) teachers in terms of classroom environment, attitudes and achievement among secondary science students. Learning Environments Research, 16, 1-21.

Johnson, B., \& McClure, R. (2004). Validity and reliability of a shortened, revised version of the Constructivist Learning Environment Survey (CLES). Learning Environments Research, 7, 65-80.

Joyce, B.A., \& Farenga, S.J. (2000). Young girls in science: Academic ability, perceptions and future participation in science. Roeper Review, 22, 261-262.

Kim, H.B., Fisher, D.L., \& Fraser, B.J. (2000). Classroom environment and teacher interpersonal behaviour in secondary school classes in Korea. Evaluation and Research in Education, 14, 3-22.

Koh, N. K., \& Fraser, B. J. (2014). Learning environment associated with use of mixed mode delivery model among secondary business studies students in Singapore. Learning Environments Research, 17, 157-171.

Koul, R.B., \& Fisher, D.L. (2005). Cultural background and students' perceptions of science classroom learning environment and teacher interpersonal behaviour in Jammu, India. Learning Environments Research, 8, 195-211.

Kvale, S. (1996). InterViews: An introduction to qualitative research interviewing. Thousand Oaks, CA: Sage.

Lincoln, Y. S., \& Guba, E. G. (1985). Naturalistic inquiry. London: Sage Publications.

Lindlof, T.R., \& Taylor, B.C. (2011). Qualitative communication research methods $\left(3^{\text {rd }}\right.$ ed.). Thousand Oaks, CA: Sage. 
Liu, L., \& Fraser, B. J. (2013). Development and validation of an English classroom learning environment inventory and its application in China. In M. S. Khine (Ed.), Application of structural equation modeling in educational research and practice (pp. 75-89). Rotterdam: Sense Publishers.

Lott, K.H. (2003). Evaluation of a statewide science inservice and outreach program: Teacher and student outcomes. Journal of Science Education and Technology, 12, 65-80.

Luan, W.S., Bakar, A.R., Mee, L.Y., \& Ayub, A.F.M. (2010). CLES-ICT: A scale to measure ICT constructivist learning environments in Malaysia. Procedia Social and Behavioral Science, 2, 295-299.

Magnusson, S., Krajcik, J., \& Borko, H. (1999). Nature, sources, and development of pedagogical content knowledge for science teaching. In J. Gess-Newsome \& N. G. Lederman (Eds.), Examining pedagogical content knowledge (pp. 95-144). Dordrecht, The Netherlands: Kluwer.

Miller, D.C., \& Warren, L.K. (2011). Comparative indicators of education in the United States and other $G-8$ countries: 2011 (NCES 2012-007). Washington, DC: U.S. Department of Education, National Center for Education Statistics.

Morgan, D.L. (1997). Practical strategies for combining qualitative and quantitative methods. Portland, OR: Portland State University Press.

Murray, H.A. (1938). Explorations in personality. New York: Oxford University Press.

National Center for Education Statistics (NCES). (2012). PISA 2012 results: Science literacy: Proficiency levels. Washington, DC: U.S. Department of Education. Retrieved from https://nces.ed.gov/surveys/pisa/pisa2012/pisa2012highlights_4.asp

Nix, R.K., Fraser, B.J., \& Ledbetter, C.E. (2005). Evaluating an integrated science learning environment using the Constructivist Learning Environment Survey. Learning Environments Research, 109-133. 
OECD. (2011). Education at a glance 2011: OECD indicators. OECD Publishing. http://dx.doi.org/10.1787/eag-2011-en

OECD. (2013). PISA 2012 results: Excellence through equity: Giving every student the chance to succeed (Volume II). OECD Publishing. http://dx.doi.org/10.1787/9789264201132-en

Ogbuehi, P.I., \& Fraser, B.J. (2007). Learning environment, attitudes and conceptual development associated with innovative strategies in middle-school mathematics. Learning Environments Research, 10, 101-114.

Oh, P.S., \& Yager, R.E. (2004). Development of constructivist science classrooms and changes in student attitudes toward science learning. Science Education Journal, 15, 105-113.

Oser, R., \& Fraser, B.J. (2015). Effectiveness of virtual laboratories in terms of learning environment, attitudes and achievement among high-school genetics students. Curriculum and Teaching, 30 (2), 65-80.

Ozkal, K., Tekkaya, C., Cakiroglu, J., \& Sungur, S. (2009). A conceptual model of relationships among constructivist learning environment perceptions, epistemological beliefs, and learning approaches. Learning and Individual Differences, 19, 71-79.

Patton, M. (2002). Qualitative research and evaluation method (3rd ed.). Thousand Oaks, CA: Sage Publications.

Reinhiller, N. (1996). Co-teaching: New variations on a not so new practice. Teaching Education and Special Education, 19, 34-48.

Robinson, E., \& Fraser, B.J. (2013). Kindergarten students' and parents' perceptions of science classroom environments: Achievement and attitudes. Learning Environments Research, 16, 151-167. 
Roth, W.-M., Lawless, D.V., \& Tobin, K. (2000). \{Coteaching/cogenerative dialoguing\} as praxis of dialectic method. Forum Qualitative Sozialforschung/ Forum: Qualitative Social Research, 1, Article 37.

Seiler, G. (2001). Reversing the "standard" direction: Science emerging from the lives of African American students. Journal of Research in Science Teaching, 38, 1000-1014.

Seiler, G., \& Elmesky, R. (2007). The role of communal practices in the generation of capital and emotional energy among African American students in science classrooms. Teachers College Record, 109, 391-419.

Spinner, H., \& Fraser, B.J. (2005). Evaluation of an innovative mathematics program in terms of classroom environment, student attitudes, and conceptual development. International Journal of Science and Mathematics Education, 3, 267-293.

Taylor, B.A., \& Fraser, B.J. (2013). Relationships between learning environment and anxiety. Learning Environments Research, 16, 297-313.

Taylor, P.C., Fraser, B.J., \& Fisher, D.L. (1997). Monitoring constructivist classroom learning environments. International Journal of Educational Research, 27, 293-302.

Thurstone, L.L. (1928). Attitudes can be measured. American Journal of Sociology, 33, 529554.

Tobin, K. (2006). Learning to teach through coteaching and cogenerative dialogue. Teaching Education, 17, 133-142.

Tobin, K., \& Fraser, B.J. (1998). Qualitative and quantitative landscapes of classroom learning environments. In B.J. Fraser and K.G. Tobin (Eds.), The international handbook of science education (pp. 623-640). Dordrecht, The Netherlands: Kluwer.

Tobin, K., \& Roth, W.-M. (2005). Implementing coteaching and cogenerative dialoguing in urban science education. School Science and Mathematics, 105, 313-322. 
Tobin, K., Elmesky, R., \& Seiler, G. (2005). Improving urban science education: New roles for teachers, students, \& researchers. Lanham, MD: Littlefield Publishing Group.

Walker, S.L. (2006). Development and validation of the Test of Geography-Related Attitudes (ToGRA). The Journal of Geography, 105, 175-181.

Wong, A.F.L., \& Fraser, B.J. (1996). Environment-attitude associations in the chemistry laboratory classroom. Research in Science and Technological Education, 14, 91-102.

Wong, A.F.L., Young, D.J., \& Fraser, B.J. (1997). A multilevel analysis of learning environments and student attitudes. Educational Psychology, 17, 449-468.

Zandvliet, D.B., \& Fraser, B.J. (2004). Learning environments in information and communications technology classrooms. Technology, Pedagogy and Education, 13, 97-123. 


\section{Appendix}

Factor loadings, percentages of variance, eigenvalues and internal consistency reliability (Cronbach alpha coefficient) for the pretest and posttest for the QuALESA

\begin{tabular}{|c|c|c|c|c|c|c|c|c|c|c|c|c|c|c|}
\hline \multirow{3}{*}{ Item } & \multicolumn{14}{|c|}{ Factor Loadings } \\
\hline & \multicolumn{2}{|c|}{ Involvement } & \multicolumn{2}{|c|}{ Cooperation } & \multicolumn{2}{|c|}{$\begin{array}{l}\text { Personal } \\
\text { Relevance }\end{array}$} & \multicolumn{2}{|c|}{$\begin{array}{l}\text { Critical } \\
\text { Voice }\end{array}$} & \multicolumn{2}{|c|}{$\begin{array}{l}\text { Shared } \\
\text { Control }\end{array}$} & \multicolumn{2}{|c|}{$\begin{array}{l}\text { Attitude to } \\
\text { Scientific } \\
\text { Inquiry }\end{array}$} & \multicolumn{2}{|c|}{$\begin{array}{c}\text { Enjoyment } \\
\text { of Science } \\
\text { Lessons }\end{array}$} \\
\hline & Pre & $\overline{\text { Post }}$ & Pre & $\overline{\text { Post }}$ & Pre & $\overline{\text { Post }}$ & $\overline{P r e}$ & $\overline{\text { Post }}$ & Pre & $\overline{\text { Post }}$ & Pre & Post & Pre & Post \\
\hline Invo1 & 0.70 & 0.70 & & & & & & & & & & & & \\
\hline Invo2 & 0.75 & 0.75 & & & & & & & & & & & & \\
\hline Invo3 & 0.42 & 0.58 & & & & & & & & & & & & \\
\hline Invo4 & 0.65 & 0.47 & & & & & & & & & & & & \\
\hline Invo5 & 0.57 & 0.73 & & & & & & & & & & & & \\
\hline Invo7 & 0.39 & 0.41 & & & & & & & & & & & & \\
\hline Invo8 & 0.35 & 0.35 & & & & & & & & & & & & \\
\hline Coop 1 & & & 0.70 & 0.67 & & & & & & & & & & \\
\hline Coop 2 & & & 0.60 & 0.72 & & & & & & & & & & \\
\hline Coop 3 & & & 0.71 & 0.73 & & & & & & & & & & \\
\hline Coop 4 & & & 0.67 & 0.71 & & & & & & & & & & \\
\hline Coop 5 & & & 0.61 & 0.32 & & & & & & & & & & \\
\hline Coop 6 & & & 0.69 & 0.79 & & & & & & & & & & \\
\hline Coop 7 & & & 0.61 & 0.72 & & & & & & & & & & \\
\hline Coop 8 & & & 0.38 & 0.43 & & & & & & & & & & \\
\hline PRel1 & & & & & 0.71 & 0.74 & & & & & & & & \\
\hline PRel2 & & & & & 0.72 & 0.65 & & & & & & & & \\
\hline PRel3 & & & & & 0.72 & 0.69 & & & & & & & & \\
\hline PRel4 & & & & & 0.78 & 0.75 & & & & & & & & \\
\hline PRel5 & & & & & 0.67 & 0.53 & & & & & & & & \\
\hline PRel6 & & & & & 0.74 & 0.73 & & & & & & & & \\
\hline CriVo1 & & & & & & & 0.80 & 0.70 & & & & & & \\
\hline CriVo2 & & & & & & & 0.76 & 0.79 & & & & & & \\
\hline CriVo3 & & & & & & & 0.74 & 0.79 & & & & & & \\
\hline CriVo4 & & & & & & & 0.66 & 0.80 & & & & & & \\
\hline CriVo5 & & & & & & & 0.61 & 0.71 & & & & & & \\
\hline CriVo6 & & & & & & & 0.61 & 0.74 & & & & & & \\
\hline SCon 1 & & & & & & & & & 0.71 & 0.65 & & & & \\
\hline SCon2 & & & & & & & & & 0.77 & 0.74 & & & & \\
\hline SCon3 & & & & & & & & & 0.78 & 0.81 & & & & \\
\hline SCon 4 & & & & & & & & & 0.77 & 0.76 & & & & \\
\hline SCon5 & & & & & & & & & 0.71 & 0.74 & & & & \\
\hline SCon6 & & & & & & & & & 0.72 & 0.70 & & & & \\
\hline ATSI1 & & & & & & & & & & & 0.78 & 0.74 & & \\
\hline ATSI2 & & & & & & & & & & & 0.78 & 0.76 & & \\
\hline ATSI3 & & & & & & & & & & & 0.69 & 0.75 & & \\
\hline ATSI4 & & & & & & & & & & & 0.73 & 0.82 & & \\
\hline ATSI5 & & & & & & & & & & & 0.78 & 0.74 & & \\
\hline ATSI6 & & & & & & & & & & & 0.80 & 0.77 & & \\
\hline EOSL1 & & & & & & & & & & & & & 0.80 & 0.77 \\
\hline EOSL2 & & & & & & & & & & & & & 0.81 & 0.84 \\
\hline EOSL3 & & & & & & & & & & & & & 0.77 & 0.73 \\
\hline EOSL4 & & & & & & & & & & & & & 0.80 & 0.87 \\
\hline EOSL5 & & & & & & & & & & & & & 0.78 & 0.75 \\
\hline EOSL6 & & & & & & & & & & & & & 0.84 & 0.79 \\
\hline$\%$ Variance & 4.58 & 3.95 & 6.55 & 9.05 & 5.37 & 4.72 & 4.73 & 7.84 & 7.06 & 5.65 & 8.88 & 6.84 & 22.73 & 21.77 \\
\hline Eigenvalue & 2.06 & 1.81 & 2.94 & 4.16 & 2.42 & 2.17 & 2.13 & 3.61 & 3.18 & 2.60 & 3.99 & 3.15 & 10.23 & 10.01 \\
\hline Reliability & 0.72 & 0.76 & 0.82 & 0.83 & 0.86 & 0.85 & 0.84 & 0.87 & 0.86 & 0.85 & 0.88 & 0.87 & 0.94 & 0.92 \\
\hline
\end{tabular}

$N=142$ ( $\mathrm{N}=82$ students in 5 classes in Dresden) ( $\mathrm{N}=60$ students in 2 classes in the Bronx)

Factor loadings less than 0.35 have been omitted from the table.

Principal axis factoring with varimax rotation and Kaiser normalisation. 


\section{List of figures}

Fig. 1 Differences between students from Dresden and the Bronx in QuALESA scale scores for pretest and posttest. 
Differences Between Dresden ( $\mathrm{N}=\mathbf{8 2}$ students) and the Bronx ( $N=60$ students) for QuALESA Pretest and Posttest



Fig. 1 
Table 1 Scale description and sample item for each scale selected from the CLES, WIHIC and TOSRA for inclusion in the QuALESA

\begin{tabular}{|c|c|c|c|c|}
\hline Instrument & Scale & Description & Sample Item & Number of Items \\
\hline CLES & Personal Relevance & $\begin{array}{l}\text { The extent to which } \\
\text { school science connects } \\
\text { with students' out-of- } \\
\text { school experiences }\end{array}$ & $\begin{array}{l}\text { I learn how science } \\
\text { can be part of my } \\
\text { out-of-school life. }\end{array}$ & 6 \\
\hline CLES & Critical Voice & $\begin{array}{l}\text { The extent to which } \\
\text { students can express a } \\
\text { critical opinion about the } \\
\text { learning environment }\end{array}$ & $\begin{array}{l}\text { It's OK for me to } \\
\text { question the way I'm } \\
\text { being taught. }\end{array}$ & 6 \\
\hline CLES & Shared Control & $\begin{array}{l}\text { The extent to which } \\
\text { students are invited to } \\
\text { share control of the } \\
\text { learning environment with } \\
\text { the teacher }\end{array}$ & $\begin{array}{l}\text { I help the teacher to } \\
\text { decide which } \\
\text { activities are best for } \\
\text { me. }\end{array}$ & 6 \\
\hline WIHIC & Involvement & $\begin{array}{l}\text { The extent to which } \\
\text { students have attentive } \\
\text { interest, participate in } \\
\text { discussions, do additional } \\
\text { work and enjoy the class }\end{array}$ & $\begin{array}{l}\text { I discuss ideas in } \\
\text { class. }\end{array}$ & 8 \\
\hline WIHIC & Cooperation & $\begin{array}{l}\text { The extent to which } \\
\text { students cooperate rather } \\
\text { than compete with one } \\
\text { another on learning tasks }\end{array}$ & $\begin{array}{l}\text { I learn from other } \\
\text { students in this class. }\end{array}$ & 8 \\
\hline TOSRA & $\begin{array}{l}\text { Attitudes to } \\
\text { Scientific Inquiry }\end{array}$ & $\begin{array}{l}\text { Attitude to scientific } \\
\text { experimentation and } \\
\text { inquiry as ways of } \\
\text { obtaining information } \\
\text { about the natural world }\end{array}$ & $\begin{array}{l}\text { I would prefer to do } \\
\text { my own experiments } \\
\text { than to find out } \\
\text { information from a } \\
\text { teacher. }\end{array}$ & 6 \\
\hline TOSRA & $\begin{array}{l}\text { Enjoyment of } \\
\text { Science Lessons }\end{array}$ & $\begin{array}{l}\text { Student satisfaction with } \\
\text { their science learning } \\
\text { experiences at school }\end{array}$ & $\begin{array}{l}\text { I find science lessons } \\
\text { to be exciting and } \\
\text { interesting. }\end{array}$ & 6 \\
\hline
\end{tabular}


Table 2 Between-country differences for QuALESA scales for pretest and posttest

\begin{tabular}{|c|c|c|c|c|c|c|c|}
\hline \multirow[t]{2}{*}{ Scale } & \multirow[t]{2}{*}{ Occasion } & \multicolumn{2}{|c|}{$\begin{array}{c}\text { Average Item } \\
\text { Mean }\end{array}$} & \multicolumn{2}{|c|}{$\begin{array}{c}\text { Average Item } \\
\text { Standard Deviation }\end{array}$} & \multicolumn{2}{|c|}{ Difference } \\
\hline & & Dresden & Bronx & Dresden & Bronx & $F$ & $\begin{array}{c}\text { Effect } \\
\text { Size }\end{array}$ \\
\hline \multicolumn{8}{|c|}{ Learning Environment } \\
\hline Involvement & $\begin{array}{l}\text { Pretest } \\
\text { Posttest }\end{array}$ & $\begin{array}{l}3.31 \\
3.28\end{array}$ & $\begin{array}{l}3.67 \\
3.36\end{array}$ & $\begin{array}{l}0.59 \\
0.58\end{array}$ & $\begin{array}{l}0.51 \\
0.59\end{array}$ & $\begin{array}{l}1.99 * * * \\
0.92\end{array}$ & $\begin{array}{l}0.65 \\
0.13\end{array}$ \\
\hline Cooperation & $\begin{array}{l}\text { Pretest } \\
\text { Posttest }\end{array}$ & $\begin{array}{l}3.61 \\
3.83\end{array}$ & $\begin{array}{l}3.24 \\
3.79\end{array}$ & $\begin{array}{l}0.54 \\
0.52\end{array}$ & $\begin{array}{l}0.71 \\
0.69\end{array}$ & $\begin{array}{l}1.87 * * \\
0.66\end{array}$ & $\begin{array}{l}0.58 \\
0.06\end{array}$ \\
\hline $\begin{array}{l}\text { Personal } \\
\text { Relevance }\end{array}$ & $\begin{array}{l}\text { Pretest } \\
\text { Posttest }\end{array}$ & $\begin{array}{l}3.63 \\
3.72\end{array}$ & $\begin{array}{l}3.04 \\
3.52\end{array}$ & $\begin{array}{l}0.77 \\
0.74\end{array}$ & $\begin{array}{l}0.58 \\
0.61\end{array}$ & $\begin{array}{l}2.22 * * * \\
1.30\end{array}$ & $\begin{array}{l}0.86 \\
0.29\end{array}$ \\
\hline Critical Voice & $\begin{array}{l}\text { Pretest } \\
\text { Posttest }\end{array}$ & $\begin{array}{l}3.64 \\
3.77\end{array}$ & $\begin{array}{l}2.82 \\
3.70\end{array}$ & $\begin{array}{l}0.74 \\
0.92\end{array}$ & $\begin{array}{l}0.76 \\
0.77\end{array}$ & $\begin{array}{l}2.48 * * * \\
0.70\end{array}$ & $\begin{array}{l}1.09 \\
0.08\end{array}$ \\
\hline Shared Control & $\begin{array}{l}\text { Pretest } \\
\text { Posttest }\end{array}$ & $\begin{array}{l}2.34 \\
2.58\end{array}$ & $\begin{array}{l}2.20 \\
2.61\end{array}$ & $\begin{array}{l}0.74 \\
0.83\end{array}$ & $\begin{array}{l}0.76 \\
0.74\end{array}$ & $\begin{array}{l}1.06 \\
0.45\end{array}$ & $\begin{array}{l}0.18 \\
0.03\end{array}$ \\
\hline $\begin{array}{l}\text { Attitudes } \\
\text { Scientific } \\
\text { Inquiry }\end{array}$ & $\begin{array}{l}\text { Pretest } \\
\text { Posttest }\end{array}$ & $\begin{array}{l}4.08 \\
4.09\end{array}$ & $\begin{array}{l}3.58 \\
3.89\end{array}$ & $\begin{array}{l}0.82 \\
0.83\end{array}$ & $\begin{array}{l}0.95 \\
0.70\end{array}$ & $\begin{array}{l}1.83^{* *} \\
1.25\end{array}$ & $\begin{array}{l}0.56 \\
0.16\end{array}$ \\
\hline $\begin{array}{l}\text { Enjoyment of } \\
\text { Lessons }\end{array}$ & $\begin{array}{l}\text { Pretest } \\
\text { Posttest }\end{array}$ & $\begin{array}{l}3.81 \\
3.74\end{array}$ & $\begin{array}{l}3.07 \\
3.55\end{array}$ & $\begin{array}{l}0.88 \\
0.88\end{array}$ & $\begin{array}{l}0.67 \\
0.69\end{array}$ & $\begin{array}{l}2.32 * * * \\
1.17\end{array}$ & $\begin{array}{l}0.94 \\
0.24\end{array}$ \\
\hline
\end{tabular}

